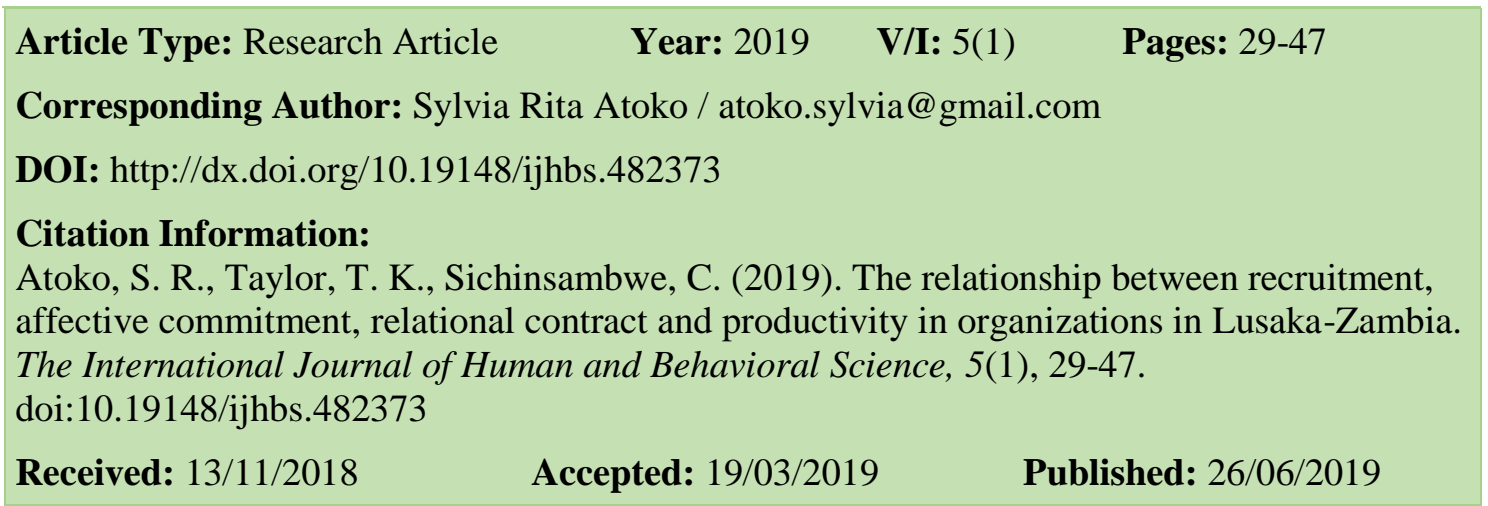

\title{
The Relationship between Recruitment, Affective Commitment, Relational Contract and Productivity in Organizations in Lusaka-Zambia
}

\author{
Sylvia Rita Atoko, The Copperbelt University, Zambia \\ ORCID: https://orcid.org/0000-0002-9643-7324
}

Thomas Kweku Taylor, The Copperbelt University, Zambia ORCID: https://orcid.org/0000-0002-3403-1089

Chanda Sichinsambwe, The Copperbelt University, Zambia ORCID: https://orcid.org/0000-0003-4242-4162

\begin{abstract}
The aim of this research was to empirically establish the relationship between recruitment, affective commitment, relational contract and productivity in selected Lusaka based organizations in Zambia. The Organizational Commitment Theory, Relational Theory of Contract, and Social Exchange Theory guided the conceptualization of the research on the assumption that, recruitment or engagement of employees encapsulates in a perceived relational trust between the employer and the employee; In other words, each party to the contractual agreement on employment engagement know their respective roles. From the conceptual postulation, the following hypotheses emerged: there is a relationship between recruitment and productivity; there is a relationship between recruitment and affective commitment; there is a relationship between recruitment and relational contract, there is a relationship between affective commitment and productivity; and finally, there is a relationship between relational contract and productivity. The methodology was a cross-sectional descriptive survey. A Structural Equation Modeling (SEM) utilizing latent variables and partial leastsquares (LVPLS) was employed for the analysis. The results indicated that, there is a relationship between recruitment and productivity, affective commitment and relational contract. Contrary, there is no relationship between relational contract and affective commitment on productivity. The conclusion was that, there is a relationship between recruitment, affective commitment and relational contract.
\end{abstract}

Keywords: Recruitment, Affective Commitment, Relational Contract, Productivity, Lusaka, Zambia

\section{Introduction}

According to Armstrong (2006), Recruitment is a positive process of searching for prospective employees and stimulating them to apply for the jobs in the organization. Consequently, human resource managers are expected to come up with innovative and strategic methods of recruiting and retaining the right employees, at the right time in the right places. These employees should 
be able to effectively perform various tasks in the organization in order to enable organizations to achieve their objectives. In addition, identifying the right talents with the requisite skills and academic qualifications in contemporary business environment has been cited by Adebola and Banjo (2017), Pushpendra, Garima, Monika and Albert (2017), Saddam and Mansur (2015); Ekwoaba, Ikeije and Ufoma (2015); Gamage (2014); and Ofori and Aryeetey (2011) as dependent on other critical traits, and characteristics of the potential employee. According to Adebola and Banjo (2017), recruitment and selection as a human resources management function, is one of the activities that impact most critically on the performance of an organization. Complimenting on this view, Azzam and Jaradat (2014), Saddam and Mansur, (2015), Ekwoaba et al. (2015), Gamage (2014), and Ofori and Aryeetey (2011) stressed that human capital has been recognized to be of significant importance in any organizational vision and strategic formulation processes. Specifically, Gamage (2014) stated that, the quality of human resource the firm has heavily depends on the effectiveness of recruitment and selection. Interestingly, Ofori and Aryeetey (2011) had earlier opined that, the overall aim of recruitment and selection within the organization is to obtain the number and qualities of employees that are required to satisfy strategic objectives of the organization at minimal cost. Similar sentiments were expressed by Brewster and Mayrhofer (2012) when they asserted that, recruitment and selection processes are crucial as they ensure that the right staff joins the organization, thereby helping the institution to meet its short and long term objectives (see also Niles, 2013). The thoughts of Brewster and Mayrhofer, Niles, and Ofori and Aryeetey, supported the view of Sangeetha (2010) on recruitment. Sangeetha (2010) affirmed that, recruitment process involves the sourcing, advertising and interviewing of future employees. This statement is very cardinal in human resource management practice in organizations (Adebola \& Banjo, 2017; Kanyamba, Iwu \& Allen-Ile, 2015; Brewster \& Mayrhofer, 2012; Ofori \& Aryeetey 2011). The definitions highlighted above show evidence of the recognition linked to aspects of the rare and unique talent possession, acquisition, and skills individuals have and are utilized by organizations (Saddam \& Mansur, 2015; Opatha, 2010). However, Opatha (2010) disclosed that, human resources management as an organizational function focuses on effective and efficient utilization of the human resources through recruitment, management, and providing direction to the employees to achieve organizational objectives. In view of this thought, Ekwoaba et al. (2015, p.22) stressed that people are vital to organizations as they offer perspectives, values and attributes to organizational life; and when managed effectively, their traits can be of considerable benefits to the organization. Hanna et al. (2014) after a critical observation, reflections and analysis on the human resources of Iraq, vis-à-vis foreign direct investment in the oil and electricity sectors, was convinced that the country possesses a dearth of qualified and skilled human capital which will be significantly needed for the development of the sector and the country. In essence, most of the researchers are of the view that recruitment and selection by organizations are strategic and conscious human resource practice engaged to identify the right talents, with the right skills and are potential to be trained and managed.

Based on the thoughts expressed in the literature on talent management, Oaya, Ogbu and Remilekun (2017) defined recruitment as the discovering of potential candidates for actual or anticipated organizational vacancies. Opatha (2010), on the other hand, perceives recruitment as the process of finding and attracting suitable qualified people. Though the issue of qualification and skills are paramount in the definition of recruitment, Ofori and Aryeetey (2011) recognized recruitment to be a procedure by an organization to generate competent individual pool to apply for employment within an organization. All the views expressed by the different authors on what recruitment is, are fascinating. However, the definition by Henry and Temtime (2009) that, recruitment is an entrance of human capital into an organization is quite intriguing. This paper recognizes recruitment as the effort made by organizations to attract a large number of qualified applicants who possess the requisite qualification, talents, and skills that will readily contribute to organizational creativity, product and service enhancement, whilst providing opportunities for service innovations and quality assurance. This perception seems to be supported by (Armstrong, 
2006) when he expressed that, recruitment can be described as those activities in human resource management which are undertaken in order to attract sufficient job candidates who have the necessary potential, competencies and traits to fill job needs and to assist the organization in achieving its objectives whilst projecting a positive image of the organization to outsiders. Undoubtedly, the significance of human capital in organizational performance via increase and sustained productivity is acknowledged by researchers, practitioners of human resource practices and management of organizations. Relating to human capital's sustained performance and commitment to the organization are affective commitment (i.e., the issue of employees' emotional attachment to the organization) and relational contract (i.e., the unwritten relationship based on trust and belief that each party to the contract will adhere to their roles).

\subsection{The Problem}

Research to empirically illustrate the linkages between recruitment, affective commitment, relational contract and productivity in organizations has not been either intense or seriously pursued. A few researchers, i.e., Ofobruku et al. (2013) and Gamage (2014) included affective commitment in their research to show the relationship between recruitment and organizational productivity. In Zambia, no attempt has been made by researchers on human resource practices and management to show the linkages between recruitment, affective commitment, relational contract and productivity. The research output that seems to dominate the literature on human resources practice and management is the relationship between human resource management practice and reward system, motivation and organizational commitment, reward system, motivation and retention in organizations performance management system and organizational commitment and performance. This study thus, made an effort to empirically validate the linkages between recruitment, affective commitment, and relational contract subsequently enhancing productivity in organizations. The study focused on Lusaka based organizations in Zambia.

The next section of this paper discusses briefly the study area. The third section provides a review of the literature related to the study. This is followed by brief theoretical underpinnings directing the conceptualization of the study. The fourth part outlines the methodology of the study. The last two parts are devoted to the results and discussion and the conclusions and recommendations respectively.

\subsubsection{Distribution of Labour Force of Zambia (2012 and 2014)}

This paper highlights some interesting statistics to illustrate how the recruitment and distribution of labour within the economy has been in the last 6 years. Statistics indicate that, agriculture, forestry and fisheries employ the largest labour force (i.e., $52.2 \%$ in 2012 and $48.9 \%$ in 2014), even though copper mining activities constitute the main foreign exchange earner of the economy. Ironically, mining employed $1.6 \%$ and $1.4 \%$ of the total labour force for the years 2012 and 2014 respectively. The other major sectors of employment within the economy are informal sector with Activities of Household as the Employer constituting 13.1\% (2012) and 17.4\% (2014) whilst Trade, Wholesale and Retail Distribution constituted $11.7 \%$ in year 2012 and $11.8 \%$ in 2014 (see Statistics generated by the Central Statistical Office of Zambia from the Labour Force Surveys of 2012 and 2014 respectively).

The 2014 statistics on the labour force distribution show some areas of the Zambian economy experiencing drop in numbers whilst others had increases, i.e., Agriculture, Forestry and Fisheries, Mining and Quarrying, and Manufacturing. The reasons for the drop in labour force in some of the sectors could be explained by the retrenchments the sectors carried out between 2012 and 2015 especially when the Zambian economy experienced a slump with the currency (the 
Kwacha) depreciating. This affected both the mining and manufacturing sectors. Invariably, the informal sector activities had an increase in the labour force when people become self-employed.

This statistic has been presented to show how the various sectors are affected by turnover of employees and recruitment in other sectors. The question begs the thematic issues related to affective commitment, continuous commitment, normative commitment, relational contract and organizational performance. The broad picture of the labour force of the Zambian economy illustrates how some of the institutions struggle with recruitment, and the three commitment concepts. Statistics also highlight that Lusaka and Copperbelt Provinces constituted $32.2 \%$ in 2012 and $33.8 \%$ in 2014. This is basically because most of the manufacturing, mining trade, commerce and services and telecommunications activities are concentrated along the line of rail. Though the figures constitute both urban and rural labour force statistics, it is clearly discerned that, Lusaka Province attracts more potential labour to be recruited in the diverse economic, administrative and services activities, i.e., construction, manufacturing, transportation and services sectors such as tourism, electricity, water supply, sewerage and water management, financial and insurance activities and real estate activities.

Table 1 below illustrates the share of Lusaka Province in the distribution of 2012 national labour force by occupation. The statistics indicate that apart from Skilled Agricultural, Forestry and Fisheries Workers which Lusaka Province had only $1.9 \%$ the rest of the occupations showed that Lusaka Province had more than $25 \%$ of the share. The statistics further illustrates that Lusaka City and Lusaka Province as a whole cumulatively have approximately $19 \%$ of the total labour force. The intriguing aspect of the statistics is that, it shows the City of Lusaka's potential economic niches where investments are made and how the human resource units of the economic institutions and organizations focus their attention on recruitments, selection, and retention. Hence, the study to establish the relationship between recruitment, affective commitment, relational contract, and productivity is very cardinal in a highly mega-metropolitan environment of Lusaka where the main institutionalized activities focus on Elementary Occupations, Clerical Support Workers and Services and Sales Workers constituting $77.28 \%$ of Lusaka Province labour force

Table 1: Labour Force Distribution by Occupation in Zambia and Lusaka Province (2012)

\begin{tabular}{lrrrr}
\hline Occupation & $\begin{array}{c}\text { National } \\
\text { Figures }\end{array}$ & $\begin{array}{r}\text { \% } \\
\text { Province } \\
\text { Number }\end{array}$ & $\begin{array}{r}\text { \% } \\
\text { Nusaka }\end{array}$ \\
\hline 1. Managers & 52,194 & 0.95 & 24,479 & 46.9 \\
2. Professionals & 218,034 & 3.96 & 56,689 & 26.0 \\
3. Technicians and Associate Professionals & 74,332 & 1.35 & 27,800 & 37.4 \\
4. Clerical Support Workers & 36,854 & 0.67 & 16,437 & 44.6 \\
5. Services and Sales Workers & 769,737 & 13.70 & 273,257 & 35.5 \\
6. Skilled Agricultural, Forestry and Fisheries & $2,676,600$ & 48.67 & 50,855 & 1.9 \\
Workers & & & & \\
7. Craft and Related Trades Workers & 378,840 & 6.89 & 111,000 & 29.3 \\
8. Plant and Machine Operators and Assemblers & 147,171 & 2.67 & 51,510 & 35.0 \\
9. Elementary Occupations & $1,136,605$ & 20.67 & 404,631 & 35.6 \\
10. Others & 8,754 & 0.16 & 4,044 & 46.2 \\
11. Not Stated & 553 & 0.01 & & \multicolumn{1}{c}{0.0} \\
\hline TOTAL & $\mathbf{5 , 4 9 9 , 6 7 3}$ & $\mathbf{1 0 0}$ & $\mathbf{1 , 0 2 0 , 7 0 2}$ & $\mathbf{1 8 . 6}$ \\
\hline
\end{tabular}

Source: Central Statistical Office (2013) Zambia Labour Force Survey 2012, Ministry of Labour and Social Security 
Interestingly, the main areas of economic investments attracting recruitment, affective commitment and relational contract include construction and Engineering, Banking and Financial Services, Food and Beverages, Transport and Communications, Retail services, Real Estate, and Oil and Gas institutions. It must be recognized that Lusaka being the capital city of Zambia, attracts all the institutional headquarters for sectors of the economy including agriculture, mining, and the hospitality industry. Though the statistics provided above provide evidence for the study to be carried out in Lusaka, other supportive reasons include, the continuous increase in investments due to government's desire and willingness to create conducive industrial environment by providing Multi-Facility Economic Zones (MFEZ).

\subsection{Literature Review}

The plethora of empirical literature on recruitment and selection and organizational performance had revealed some interesting outcomes. For instance, Oaya, Ogbu and Remilekun (2017); Pushpendra et al. (2017); Dahie (2017); Adebola and Banjo (2017) Karia et al. (2016), Ekwoaba et al. (2015); Gamage (2014); Muslim et al. (2014) and Ofobruku et al. (2013) all found a significant relationship between recruitment and productivity.

In line with this study, the publications by Gamage (2014) and Ofobruku et al. (2013) had some partial relationships. Whilst Gamage (2014) focused his research on the relationship between recruitment, affective commitment and productivity, Ofobruku et al. concentrated on recruitment, relational contract and productivity. In addition, the research by Gamage (2014) focused on the link between recruitment, affective commitment and productivity and established positive relationships between the variables. Both research outcomes indicated positive relationships between the variables. In addition, Gamage (2014) noted that, the recruitment and selection practices determined who was hired, shaped by the employee behaviour and attitude. The inference made from the research was that, if recruitment and selection is properly designed and executed, it will identify competent candidates and accurately match them to the job. Hence, it was concluded that the use of the proper selection device increased the probability that the right person was chosen to fill a slot. Thus, when the best (i.e., well qualified and possessing the right attitude and behavior) people were selected for the job, productivity is likely to increase. Interestingly, in the case of Ofobruku et al. (2013), who assessed the impact of recruitment practices on the organization performance in the hospitality industry in Abuja, it was ascertained that, for the hospitality business to attract and engage best suitable employees with the right knowledge skills and attitudes to steer the day to day operation of the businesses, the institutions must adhere to keeping good staff, gain employee and guest/customers loyalty that improve their market share, this could be achieved through the employment of best practice in employee recruitment.

Oaya, Ogbu and Remilekun (2017) conducted a study on the impact of recruitment and selection strategy on employees' performance. The outcome was that the use of recruitment agency and internal employee recommendation in the recruitment / selection process enabled organizations to recruit committed and productive employees while the recruitment through the influence of host community led to organizational inefficiency. Similarly, Pushpendra et al. (2017) conducted research studies on the recruitment and selection and its impact on organizational productivity. The research revealed that service organizations follow best recruitment and selection process and they are satisfied with the organizational environment and the organization follows decent recruitment policy (p.26).

Adebola and Banjo (2017) examined the relative effectiveness of recruitment and selection procedures on employees' performance in the hospitality industry in Ogun State of Nigeria. The overall objective of the study was to determine how recruitment and selection affected employee's 
performance in the hospitality industry in the study area. The result of the study showed that the correlation between recruitment and selection and employee's performance was highly significant. Similar results were realized by Kaira et al. (2016) on the impact of recruitment and selection on performance of public utilities in Tanzania. Contrary, Hafiz (2017) focused his study on the relationship of dimensions of organizational commitment and employee performance in both private and public banks of Lahore in Pakistan. The study discovered that three elements of organizational commitment were essential factor towards improvement of performance among banking employees. It meant that employees were willing to devote and stay in banks for accomplishment of the objectives of jobs because they had same goals and values inside the organization.

In some intriguing research studies done by Seeck et al. (2010), Obeidat et al. (2014) and Yesufu (2016) in different geographical economies on organizations and human resource practices, some insightful outcomes were disclosed. Seeck et al. (2010) explored how human resource management was currently intended, used and experienced in ten Finnish companies operating in the field of telecommunications focusing more on how psychological contracts were created and maintained, and studied their relationship with human resource management as a means of either direct or indirect control. With recruitment emerging as the top employer priority, employees voluntarily assumed the obligation to exercise organizational control as part of their psychological contract in exchange for the freedom and autonomy that they enjoyed. In view of the autonomy and freedom that employees' experience they are permitted to define what constituted their psychological contract, with a duty to control its attractiveness from the employers' point of view. Obeidat et al. (2014) on the other hand, investigated the relationship between human resources management practices and organizational commitment and their relationship with knowledge management process on consultancy firms operating in Jordan. The results of the SEM analysis indicated that human resources practices (recruitment methods, training and development, performance appraisals, and reward systems) had a significant influence on organizational commitment (affective commitment, continuance commitment, and normative commitment). Yesufu (2016) researching on higher education academics in Canada, on the effect of their perception of the human resource practices of their employers on their psychological contract, disclosed that, recruitment and selection, training and development and compensation and benefits human resource practices had significant and positive effects on the relational and balanced psychological contracts of academics, thereby building commitment, loyalty and the desire for professional and career development.

The literature reviewed had a combination of recruitment and its relationship with organizational performance (Adebola \& Banjo, 2017; Hafiz, 2017; Oaya, Ogbu \& Remilekun, 2017; Kaira et al., 2016) whilst others were specific on organizational productivity (Pushpendra et al. 2017; Kanyemba, Iwu \&Allen-Ile, 2015; Gamage, 2014; Ofobruku et al., 2013). This research focused on the latter. Thus, it is imperative to specify and highlight on the perceptions of the concept of productivity with respect to the study. Appropriately, the definitions by Catano et al. (2010), Syverson (2010), and Dechert-Hampe [DHC] (n.d) guided the adoption of the concept of productivity in the design of the questionnaire for the data collection. Syverson's definition states that, productivity is a simply expressed as output-input ratio. However, achieving the desire ratio for any organization according to Catano et al. (2010) depends on a suitable work environment that is characterized by an effective recruitment and selection process. In other words, organizational productivity is presumed to be strongly related to effective recruitment and management of the talents selected to perform their responsibilities. Other factors that are presumed to drive organizational productivity according to Dechert-Hampe Consulting $[\mathrm{DHC}](\mathrm{n} . \mathrm{d})$ include staffing, structure, communications training and development, sound objectives and supportive culture, planning better control systems, focused strategy and proper processes (See also Kanyemba, Iwu \& Allen-Ile, 2015). 
The literature review produced some insights on recruitment and selection, relational contract and affective commitment and organizational productivity. Interestingly, though the review cut across diverse geographical economies and diverse organizations, the findings seem to be complementing each other, hence providing the appropriate direction in the conceptualization of the theoretical constructs for the research.

\subsection{Theoretical constructs underlying the research}

This research utilized the assumptions underlying both the theoretical constructs of the relational theory of contract, organizational commitment theory, as well as the social exchange theory. The relational theory of contract by Ian Macneil (1978) holds that, "agreements are not always transactional occasions whereby parties exchange only value (cited in Bird, 2005, p.151). The theory further postulates that, "parties to contracts develop a relationship between one another that incorporates, planning, trust, and solidarity that far exceeds the terms of original document" (Bird, 2005). The inference from the theorization is that, employers and employees need to have a relational contract that is unwritten but must be based on mutual trust and commitment with both parties ensuring they fulfill their contractual obligations, i.e., the employee through recruitment and selection process is given the trust and confidence to work in the organization to contribute to achieving organizational productivity targets (see also Mercurio, 2015). Mecrcurio (2015, p.407) reflecting on theme of "affective commitment as a core essence of organizational commitment" stressed that, "researchers have found that developing and managing affective commitment begins at the point of recruitment and within initial entry experience in an organization". Contrary, the employer has to adhere to its part of the contractual obligations to ensure the employee has the trust and confidence in management to minimize or eliminate turnover in the organization. Thus, the relational contract is inherently characterized with a relationship of exchange which is continuous over a significant period of time (Speidel, 2000; see also Bird, 2005).

Similarly, the social exchange theory was recognized to be significantly relevant to the conceptualization of the study. The social exchange theory proposed that social behavior is the result of an exchange process the purpose of which is to maximize benefits and minimize costs (Cherry, 2018). This theory developed by George Homans illustrates that, most relationships are made up of a certain amount of give-and-take which in most cases do not work out to expectation. Thus, it is the valuing of the benefits and costs of each relationship that determine whether or not the parties to the relationship will choose to continue the association (ibid). This study thus realized that, the theories on relational contract and organizational commitment have significant relationship pivoted on the psychological expectations on the part of the employee and the employer in their performances of responsibilities and expected outcomes.

Notwithstanding the above theoretical expositions to illustrate the employees' loyalty to the organization, the influence of affective commitment perceived to be significant vis-à-vis the new recruit to the organization. Thus, the organization commitment theory (Meyer \& Allen, 1991) encapsulated in the three component model (TCM) of affective commitment, continuous commitment and normative commitment was also considered to have a significant role in the conceptualization of the study. The presumptions underlying the critical and relevant role played by the organization commitment theory are that: (a) affective commitment of the employee brings out the emotional attachment to the organization hence, the high probability of the employee to stay on in the organization and be serious engaged in the achievement of the organization goals and vision; (b) continuous commitment of the employee relating to cost benefit analysis of leaving the organization. The employee's continuous commitment to the organization is likely to be based on a decision of the cost or the negative impact he or she might experience (Allen \& Meyer, 1991). Thus, an employee with a high level of continuous commitment is perceived to have a 
higher desire to stay with the organization hence, presumed to contribute effectively and efficiently to organizational performance; and (c) normative commitment which relates to the employee feeling obliged to stay with the organization to achieve its goals. All the three components of the organizational commitment theory are very significant in the relationship between recruitment and organizational productivity. Based on the theoretical constructs and discussions above, the relationship between the concepts, i.e., recruitment, affective commitment, relational contract and productivity give rise to the following research model (see Figure 1).

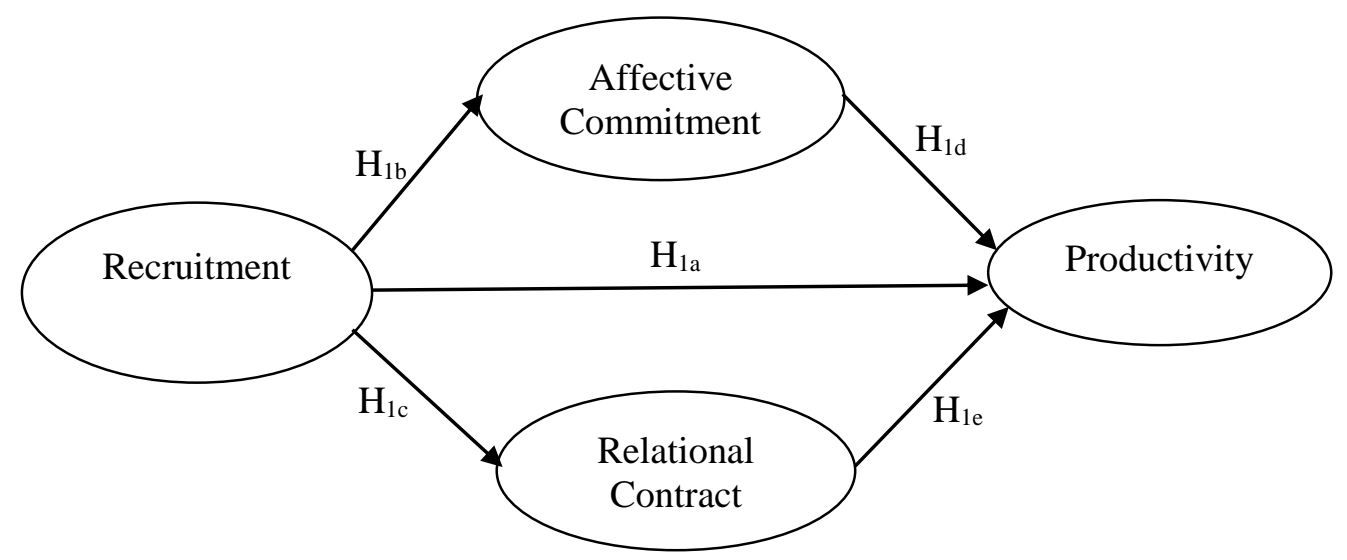

Figure 1: Research Model on Recruitment, Affective Commitment, Relational Contract and Productivity

$\mathrm{H}_{1}$ : There is a relationship between recruitment and productivity in organizations in Lusaka, Zambia.

$\mathrm{H}_{2}$ : There is a relationship between between recruitment and affective commitment in organizations in Lusaka, Zambia.

$\mathrm{H}_{3}$ : There is a relationship between between recruitment and relational contract in organizations in Lusaka, Zambia.

$\mathrm{H}_{4}$ : There is a relationship between between affective commitment and productivity in organizations in Lusaka, Zambia

$\mathrm{H}_{5}$ : There is a relationship between between relational contract and organizational productivity in Lusaka, Zambia.

\subsection{Methodology}

This research paper is one of the five research papers that have been extracted from the author's $\mathrm{PhD}$ dissertation which has been submitted for fulfillment of the Doctor of Philosophy Degree in Human Resource Management. This was a cross-sectional descriptive research survey extracted from a sample frame of 10,077 companies, all situated in Lusaka, Zambia. A Structural Equation Modeling (SEM) utilizing latent variables and partial least-squares (LVPLS) was employed for the analysis. The companies comprised of two categories small (i.e., 1 to 100 employees) and large (i.e., more than 100 employees). Besides, the research also took note of another classification which was local and foreign owned companies.

\subsubsection{Sample}

A total of 600 questionnaires were initially distributed to all the 200 hundred companies that were randomly selected to participate in the research study. Specifically, three (3) questionnaires were distributed to each of the 200 companies. The assumption was that, three (3) employees from each 
of the 200 hundred companies were expected to participate in the research study. Hence the three employees were derived from the top, middle and lower levels in each of the 200 companies. Out of the 200 companies that were selected to participate in the research study, only 99 responded. A total of 255 questionnaires were received from the 99 companies that participated in the research study. A total of 77 companies completed and each returned all the three (3) questionnaires that were given to them, resulting to 231 questionnaires. Another 9 companies completed and each returned only two (2) out of the three (3) questionnaires that were given to them, resulting to 18 questionnaires. Lastly, six (6) companies completed and each returned only one (1) out of the three (3) questionnaires that were given to them, resulting to 6 questionnaires. All the returned questionnaires totaled to 255 questionnaires. An average of responses from each of the companies that participated in the research study was determined in order to obtain only one set of data per company. Out of the 99 companies that participated in the research study, 55 were small and 44 were large. The sizes of companies was determined by the number of employees. Companies with less than 100 employees were categorized as small while companies with more than 100 employees were categorized as large.

\subsubsection{Instrument}

A self-administered questionnaire containing mostly close-ended questions was used in the collection of data. The instrument comprised of several Likert-type scale ranging between (1) representing strongly disagree and (7) representing strongly agree was used. Hence, the construction of the survey and the sub-dimensions are extensively explained below.

\subsection{Data Analysis and Results}

One structural model was formulated and tested using structural equation modeling (SEM) using latent variables partial least-squares (LVPLS) with SmartPLS3.Before convening the analysis, the original data was subjected to validity and reliability tests. The estimations revealed that factors such as AC5 RC2 RC3 and PROD5 did not meet the 0.4 threshold level as suggested by Hair et al. (2013). Interestingly, seven (7) factors R3, R4, R5, AC3, RC1, RC5, PROD2 and PROD4 were observed to have the expected loadings above (see Table 2 below). With reference to the PLS model that was being applied for the analysis, the loading relevance test was performed on the seven (7) indicator factors to ascertain if they could be maintained in the model. The main rationale was that in a loading relevance test, problematic indicators are to be deleted only if their removal from the PLS model leads to an increase of AVE and composite reliability of their constructs over the 0.5 thresholds (see Figure 2 and Table 2 below). 


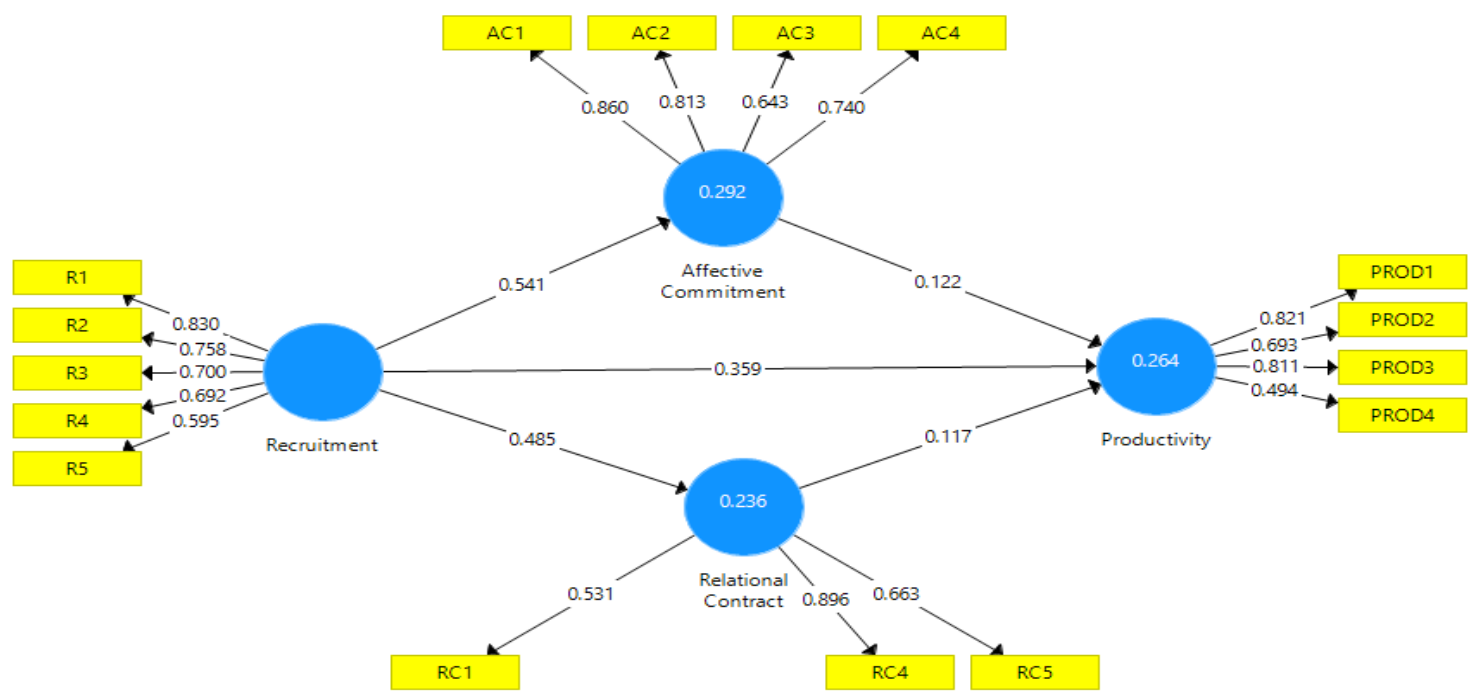

Figure 2: PLS Path Model Estimation

Furthermore, applying the PLS-SEM requires that composite reliability is estimated to validate the measurement model's internal consistency reliability. The composite reliability for the constructs RECRUITMENT, AFFECTIVE COMMITMENT, RELATIONAL CONTRACT AND PRODUCTIVITY were estimated to be $0.841,0.851,0.748$ and 0.803 respectively, The results indicate high levels of internal consistency reliability.

Table 2: Outer Loadings

\begin{tabular}{|c|c|c|c|c|}
\hline & $\begin{array}{c}\text { AFFECTIVE } \\
\text { COMMITMENT }\end{array}$ & PRODUCTIVITY & RECRUITMENT & $\begin{array}{c}\text { RELATIONAL } \\
\text { CONTRACT }\end{array}$ \\
\hline $\mathrm{AC} 1$ & 0.860 & & & \\
\hline $\mathrm{AC} 2$ & 0.813 & & & \\
\hline AC3 & 0.643 & & & \\
\hline AC4 & 0.740 & & & \\
\hline PROD1 & & 0.821 & & \\
\hline PROD2 & & 0.693 & & \\
\hline PROD3 & & 0.811 & & \\
\hline PROD4 & & 0.494 & & \\
\hline R1 & & & 0.830 & \\
\hline R2 & & & 0.758 & \\
\hline R3 & & & 0.700 & \\
\hline R4 & & & 0.692 & \\
\hline R5 & & & 0.595 & \\
\hline $\mathrm{RC} 3$ & & & & 0.531 \\
\hline $\mathrm{RC} 4$ & & & & 0.896 \\
\hline RC5 & & & & 0.663 \\
\hline
\end{tabular}

\subsubsection{Convergent Validity}

On the convergent validity, the AVE for the latent construct RECRUITMENT, AFFECTIVE COMMITMENT, RELATIONAL CONTRACT AND PRODUCTIVITY were all above the .50 threshold level with recruitment obtaining 0.517; Affective Commitment attaining 0.590,whilst Relational Contract had 0.508 with Productivity being 0.514 ' Thus, the measures of the four reflective constructs were assumed to have recorded high levels of convergent validity.

\subsubsection{Discriminant Validity}

This study went further by applying the Fornell-Larcker criterion (1981) to assess the discriminant validity since it is a requirement for the application of the PLS-SEM. Tables 3 and 4 show that discriminant validity was met because the square root of AVE for RECRUITMENT, AFFECTIVE COMMITMENT, RELATIONAL CONTRACT AND PRODUCTIVITY was 
much larger than the corresponding LVC and the indicator's loading to its latent construct was higher than that of other constructs.

Table 3: Fornell-Larker Criterion

\begin{tabular}{|c|c|c|c|c|}
\hline & $\begin{array}{c}\text { AFFECTIVE } \\
\text { COMMITMENT }\end{array}$ & PRODUCTIVITY & RECRUITMENT & $\begin{array}{l}\text { RELATIONAL } \\
\text { CONTRACT }\end{array}$ \\
\hline AFFECTIVE COMMITMENT & 0.768 & & & \\
\hline PRODUCTIVITY & 0.392 & 0.717 & & \\
\hline RECRUITMENT & 0.541 & 0.482 & 0.719 & \\
\hline RELATIONAL CONTRACT & 0.644 & 0.370 & 0.485 & 0.713 \\
\hline
\end{tabular}

Table 4: Cross loadings

\begin{tabular}{ccccc}
\hline & $\begin{array}{c}\text { AFFECTIVE } \\
\text { COMMITMENT }\end{array}$ & PRODUCTIVITY & RECRUITMENT & $\begin{array}{c}\text { RELATIONAL } \\
\text { CONTRACT }\end{array}$ \\
\hline AC1 & $\mathbf{0 . 8 6 0}$ & 0.405 & 0.433 & 0.544 \\
AC2 & $\mathbf{0 . 8 1 3}$ & 0.344 & 0.467 & 0.511 \\
AC3 & $\mathbf{0 . 6 4 3}$ & 0.162 & 0.359 & 0.462 \\
AC4 & $\mathbf{0 . 7 4 0}$ & 0.246 & 0.396 & 0.467 \\
PROD1 & 0.454 & $\mathbf{0 . 8 2 1}$ & 0.478 & 0.355 \\
PROD2 & 0.131 & $\mathbf{0 . 6 9 3}$ & 0.271 & 0.289 \\
PROD3 & 0.271 & $\mathbf{0 . 8 1 1}$ & 0.333 & 0.245 \\
PROD4 & 0.494 & 0.218 & 0.102 \\
R1 & 0.134 & 0.394 & $\mathbf{0 . 8 3 0}$ & 0.540 \\
R2 & 0.523 & 0.279 & $\mathbf{0 . 7 5 8}$ & 0.345 \\
R3 & 0.369 & 0.434 & $\mathbf{0 . 7 0 0}$ & 0.202 \\
R4 & 0.358 & 0.137 & $\mathbf{0 . 6 9 2}$ & 0.353 \\
R5 & 0.414 & 0.479 & $\mathbf{0 . 5 9 5}$ & 0.228 \\
RC1 & 0.228 & 0.096 & 0.313 & $\mathbf{0 . 5 3 1}$ \\
RC4 & 0.429 & 0.363 & 0.489 & $\mathbf{0 . 8 9 6}$ \\
RC5 & 0.587 & 0.285 & 0.153 & $\mathbf{0 . 6 6 3}$ \\
\hline
\end{tabular}

\subsubsection{Collinearity Assessment for the Structural Model in PLS-SEM}

Collinearity is a significantly important issue in the structural model hence the variance inflation factor (VIF) value of 5 or above is always regarded as a problem (see also Hair et al., 2011). The Table 5 provides the summary of the collinearity assessment results. The table below depicts that all the VIF values were less than five. This suggested that there was no collinearity between each set of predictor variables.

Table 5: Collinearity Assessment

\begin{tabular}{|c|c|c|c|c|}
\hline & $\begin{array}{l}\text { AFFECTIVE } \\
\text { COMMITMENT }\end{array}$ & PRODUCTIVITY & RECRUITMENT & $\begin{array}{l}\text { RELATIONAL } \\
\text { CONTRACT }\end{array}$ \\
\hline $\begin{array}{l}\text { AFFECTIVE COMMITMENT } \\
\text { PRODUCTIVITY }\end{array}$ & & 1.934 & & \\
\hline $\begin{array}{l}\text { RECRUITMENT } \\
\text { RELATIONAL CONTRACT }\end{array}$ & 1.000 & $\begin{array}{l}1.480 \\
1.791\end{array}$ & & 1.000 \\
\hline
\end{tabular}

\subsubsection{Coefficient of Determination $\left(R^{2}\right)$}

In PLS-SEM model, PRODUCTIVITY was the main construct of interest. Hence, from the PLS Path model estimation diagram (see Figure 2), the overall $R^{2}$ was discovered to be weak. Hair at el., (2013) suggested in their documentation that the value $0.25,0.5$ and 0.7 are perceived to reflect on weak, moderate, and strong coefficient of determination Thus in this research, the $R^{2}$ value of 0.264 was regarded as very weak for RECRUITMENT, AFFECTIVE COMMITMENT, and RELATIONAL CONTRACT. In other words, the three constructs jointly explain $26.4 \%$ of the variance of the dependent construct of PRODUCTIVITY. 


\subsubsection{Path Coefficient}

From Table 6 provides a summary of the significant testing results. The results indicate that the three structural model relationships were significant, i.e., RECRUITMENT $\rightarrow$ AFFECTIVE COMMITMENT, RECRUITMENT $\rightarrow$ PRODUCTIVITY, RECRUITMENT $\rightarrow$ RELATIONAL CONTRACT. The results thus enable us to conclude that, RECRUITMENT has the strongest effect on PRODUCTIVITY (0.359) with AFFECTIVE COMMITMENT (0.122) and RELATIONAL CONTRACT (0.117) being moderately significant

Table 6: Significance Testing Results of the Structural Model Path Coefficients

\begin{tabular}{lcccc}
\hline & Mean & Std dev & t-statistic & p-value \\
\hline AFFECTIVE COMMITMENT $\rightarrow$ PRODUCTIVITY & 0.125 & 0.175 & 0.699 & 0.485 \\
RECRUITMENT $\rightarrow$ AFFECTIVE COMMITMENT & 0.553 & 0.071 & 7.626 & 0.000 \\
RECRUITMENT $\rightarrow$ PRODUCTIVITY & 0.359 & 0.115 & 3.122 & 0.002 \\
RECRUITMENT $\rightarrow$ RELATIONAL CONTRACT & 0.505 & 0.064 & 7.610 & 0.000 \\
RELATIONAL CONTRACT $\rightarrow$ PRODUCTIVITY & 0.128 & 0.163 & 0.719 & 0.473 \\
\hline
\end{tabular}

1.5.6 Predictive relevance $\left(Q^{2}\right)$

Stone-Geisser's predictive relevance $\left(Q^{2}\right)$ was performed to check if the data points of indicators in the reflective measurement model of endogenous construct could be predicted accurately. This was done by making use of the blindfolding procedure in SmartPLS. AFFECTIVE COMMITMENT, RELATIONAL CONTRACT AND PRODUCTIVITY being the only endogenous constructs in the model, were used for running the Blindfolding Algorithm. Table 7 provides the summaries of the results. The results indicated that the model has good predictive relevance for the endogenous variables because the values were larger than zero (0) (See Chin 1998).

Table 7: Predictive relevance $(Q 2)$

\begin{tabular}{lcc}
\hline Endogenous Latent Variable & $\boldsymbol{R}^{2}$ Value & $\boldsymbol{Q}^{2}$ Value \\
\hline AFFECTIVE COMMITMENT & 0.292 & 0.146 \\
RELATION CONTRACT & 0.236 & 0.090 \\
PRODUCTIVITY & 0.264 & 0.098 \\
\hline
\end{tabular}

\subsubsection{The $f^{2}$ Effect Size}

Based on Cohan's (1988) guideline which stated that, $f^{2}$ values of $0.02,0.15$, and 0.35 could be interpreted as small, medium, and large effect sizes, respectively, the structural model was evaluated to assess the effect of a specific exogenous construct on the endogenous construct if it was to be deleted from the model. Table 8 provides the summaries of the $f^{2}$ effect sizes. It could be observed that RECRUITMENT had a large effect on AFFECTIVE COMMITMENT and RELATIONAL CONTRACT whilst having medium effect on PRODUCTIVITY. Contrary with effect size of 0.010 AFFECTIVE COMMITMENT and RELATIONAL CONTRACT had small size effects on PRODUCTIVITY

Table 8: The $f^{2}$ Effect Size

\begin{tabular}{|c|c|c|c|c|}
\hline & $\begin{array}{c}\text { AFFECTIVE } \\
\text { COMMITMENT }\end{array}$ & PRODUCTIVITY & RECRUITMENT & $\begin{array}{l}\text { RELATIONAL } \\
\text { CONTRACT }\end{array}$ \\
\hline AFFECTIVE COMMITMENT & & 0.010 & & \\
\hline PRODUCTIVITY & & & & \\
\hline RECRUITMENT & 0.413 & 0.119 & & 0.308 \\
\hline RELATIONAL CONTRACT & & 0.010 & & \\
\hline
\end{tabular}

\subsubsection{Multi-group Analysis (PLS-MGA) - Firm Size}

The dataset comprised of small firms and large firms in Lusaka (the indicator of measurement of size was based on the number of employees). Thus t was found expedient to conduct a multi-group analysis (PLS-MGA) using the parametric approach (see Keil et al. 2000). The approach is a modified two independent-sample $t$ test to compare path coefficient across two groups of data. Utilizing the principles for bootstrapping, the standard deviation of the path coefficient was calculated to explore if there was any categorical moderating effect of firm size (i.e., small $=$ 
group 1; large = group 2) on the research findings. This kind of concern is understandable because heterogeneity may exist to show significant differences in model relationships. The dataset had 55 small firms and 44 large firms. It was therefore important to evaluate if the variances of the PLS path coefficient differ significantly across the two groups. Table 9 is a summary of the output from the PLS_MGA analysis. As revealed in Table 11, none of the relationship differs significantly across the two groups ( $p$-value $>0.05$ ).

Table 9: Multi-group Analysis (PLS-MGA) Results

\begin{tabular}{lcc}
\hline & $\begin{array}{c}\text { Path Coefficient } \\
\text { Diff (|Firm size 1 - Firm size 2|) }\end{array}$ & $\begin{array}{c}p \text {-value } \\
\text { (Firm size 1 vs Firm size } \\
\text { 2) }\end{array}$ \\
\hline Affective Commitment $\rightarrow$ Productivity & & 0.136 \\
Recruitment $\rightarrow$ Affective Commitment & 0.369 & 0.110 \\
Recruitment $\rightarrow$ Productivity & 0.181 & 0.924 \\
Recruitment $\rightarrow$ Affective Commitment & 0.316 & 0.098 \\
Relational Contract $\rightarrow$ Productivity & 0.172 & 0.695 \\
\hline
\end{tabular}

\subsubsection{Hypothesis Testing Results}

Three of the hypotheses are supported, and their results are summarized in Table 10. RECRUITMENT is found to have significant impact on PRODUCTIVITY, RELATIONAL CONTRACT and AFFECTIVE COMMITMENT. However, there was no significant effect of RELATIONAL CONTRACT and AFFECTIVE COMMITMENT on PRODUCTIVITY hence the last two hypotheses were rejected.

Table 10: Hypothesis Testing Results Outcome

\begin{tabular}{llc}
\hline & Hypotheses & Remark \\
\hline $\mathrm{H}_{1}$ & There is a relationship between recruitment and productivity & Supported \\
$\mathrm{H}_{2}$ & There is a relationship between recruitment and affective commitment & Supported \\
$\mathrm{H}_{3}$ & There is a relationship between recruitment and relational contract & Supported \\
$\mathrm{H}_{4}$ & There is a relationship between affective commitment and productivity & Not Supported \\
$\mathrm{H}_{5}$ & There is a relationship between relational contract and productivity & Not Supported \\
$\mathrm{H}_{6}$ & There is significant categorical moderating effect of firm size on the relationship among model & Not Supported \\
& constructs. & \\
\hline
\end{tabular}

$H_{1}$ : There is a relationship between recruitment and productivity

Table 10 shows that there is a significant difference between recruitment and productivity. The result is in agreement with the findings of Zirra et al. (2017) which revealed that the use of recruitment agency and internal employee recommendation in the recruitment / selection process enabled organizations to recruit committed and productive employees while the recruitment through the influence of host community led to organizational inefficiency. In addition, Pushpendra et al. (2017) also revealed that service organizations follows best recruitment and selection process and they are satisfied with the organizational environment and the organization follows decent recruitment policy. Similarly Dahie (2017) found that organizational performance had significant positive influence with recruitment and selection, compensation and reward and performance appraisal management. Adebola and Banjo (2017), Karia et al. (2016) and Ekwoaba et al, (2015) all found a positive relationship between recruitment and selection and employee's performance. Lastly, Muslim et al. (2014) also revealed that human resource management practices, i.e., recruitment, training, performance appraisal, career planning, employee participation, job definition and compensation had a significant relationship with university performance. The result of the hypothesis therefore implies that organizations situated in Lusaka Zambia should embark on appropriate recruitment strategies and policies that will enhance organizational productivity.

\section{$\mathrm{H}_{2}:$ There is a relationship between recruitment and affective commitment}

The result in Table 10 shows that there is a significant difference between recruitment and affective commitment. The result is therefore in agreement with the findings of Gamage (2014) and Obeidat et al. (2014) who noted that the recruitment and selection practices determined who 
was hired, shaped employee behaviour and attitude. For instance, Gamage (2014) opined that when the best people were selected for the job, productivity increased. Obeidat et al. (2014) also confirmed that human resources practices (i.e., recruitment methods, training and development, performance appraisals, and reward systems) had a significant influence on organizational commitment (affective commitment, continuance commitment, and normative commitment). The result of the hypothesis therefore implies that recruitment strategies and policies that are formulated and adopted by organizations situated in Lusaka Zambia should be linked to the affective commitment of employees.

\section{$H_{3}$ : There is a relationship between recruitment and relational contract}

Table 10 shows that there is a significant difference between recruitment and relational contract. The result is in agreement with the findings of Ofobruku et al., (2013), who recommended that for the hospitality business to be successful it must adhere to keeping good staff, gain employee and guest/customers loyalty that improve their market share, this could be achieved through the employment of best practice in employee recruitment. The result is also in agreement with the findings of Yesufu (2016) and Seeck et al. (2010). Yesufu (2016) disclosed that employees' perception of the recruitment and selection, training and development and compensation and benefits of human resource practices have positive significant effects on the relational and balanced psychological contracts of academics, thereby building commitment, loyalty and the desire for professional and career development. The results by Seeck et al. (2010) on the other hand, indicated that employees voluntarily assumed the obligation to exercise organizational control as a part of their psychological contract in exchange for the freedom and autonomy that they enjoyed. The result of the hypothesis therefore implies that the management of organizations situated in Lusaka Zambia should ensure that the recruitment policies adopted are consistent with the relational contract between employees and the same organizations.

\section{$H_{4}$ : There is a relationship between affective commitment and productivity}

Table 10 shows that there is no significant difference between affective commitment and productivity. The result contradicts the findings of Gamage (2014), who noted that the recruitment and selection practices determined who was hired, shaped employee behaviour and attitude. $\mathrm{He}$ opined that when the best people were selected for the job, productivity increased.

The result of the hypothesis therefore implies that since there is no direct link between affective commitment and productivity, there is a possibility that there are mediating factors that bridge the gap between the two constructs. The managements of organizations situated in Lusaka Zambia should therefore identify and establish factors that determine the link between affective commitment and productivity.

\section{$H_{5}$ : There is a relationship between relational contract and productivity}

Table 10 shows that there is no significant difference between relational contract and productivity. The result contradicts the findings of Ofobruku et al, (2013), who recommended that for the hospitality business to be successful it must adhere to keeping good staff, gain employee and guest/customers loyalty that improve their market share, this could be achieved through the employment of best practice in employee recruitment. The result of the hypothesis therefore implies that since there is no direct link between relational contract and productivity, there is a possibility that there are mediating factors that bridge the gap between the two constructs. The managements of organizations situated in Lusaka Zambia should therefore identify and establish factors that determine the link between relational contract and productivity.

\section{$H_{6}: \quad$ There is significant categorical moderating effect of firm size on the relationship among model constructs}

Table 10 also shows that no significant categorical moderating effect of firm size is observed in this research, so the same conclusion can be drawn for both small business and large businesses. In other words, firms in Lusaka, Zambia do not need to run different human resource programmes 
to influence organizational performance (productivity). Since there is a positive relationship between recruitment and productivity, firms should prioritise recruitment policies if they are going to increase productivity and hence become more competitive in the market place. Consequently, recruitment policies should be enhanced in order to ensure continuous productivity in organizations situated in Lusaka Zambia.

\subsection{Conclusions and Recommendations}

There is a relationship between recruitment and productivity, recruitment and affective commitment, and recruitment and relational contract. This implies that the recruitment and selection process in organizations based in Lusaka, Zambia was normally very transparent. The results also imply that appointments in most organizations based in Lusaka, Zambia were based on merit. In addition, employees in most organizations based in Lusaka, Zambia were availed job descriptions during their appointments. Employees in organizations based in Lusaka, Zambia were told about all positive and negative aspects of their jobs during interviews before being employed. Majority of employees in organizations based in Lusaka, Zambia were well inducted during their appointment.

Another observation in the research study is that there is no relationship between affective commitment and productivity, and relational contract and productivity. This suggests that affective commitment and relational contract are considered to be the mediating effects of the relationship between recruitment and productivity.

Hence, organizations situated in Lusaka, Zambia should embark on strategic and innovative recruitment strategies and policies that will enable them to increase productivity and achieve their goals. Organization's strengths or weaknesses come from the quality of their employees and a good recruitment policy enables organizations to obtain and retain competent employees who will contribute towards enhancement of organizational performance. Organizations should therefore implement the organizational commitment theory, relational theory of contract, social exchange theory, Herzberg's two-factor theory, scientific management theory, expectancy theory, the equity theory among other relevant theories in their recruitment strategies, in order to realize productivity.

The study recommends that future research studies should be conducted in other parts of the country, in order to include organizations beyond Lusaka Zambia. In addition, future research studies should also make use of other data collection instruments i.e. observation guides, interview schedules and focussed group discussions, in addition to the questionnaire in order to collect more detailed data for the study.

\section{References}

Adebola, Y. B., \& Banjo, K. A. (2017). Recruitment and Selection Procedures and their Relative Effectiveness on Employees' Performance in the Hospitality Industry in Ogun State. International Journal of the Guild of Contemporary Academic Researchers (IJGCAR), 2(2), 55-62.

Allen, N. J., \& Meyer, J. P. (1990). The measurement and antecedents of affective, continuance and normative commitment to the organization. Journal of Occupational Psychology, 63(1), 1-18.

Anderson, J.C., \& Gerbing, D.W. (1988). Structural equation modeling in practice: a review and recommended two-step approach. Psychological Bulletin, 103(3), 411-423.

Armstrong, M. (2006). Human Resource Management Practice (10 ${ }^{\text {th }}$ ed.). Kogan Page Limited Publishers, London. 
Armstrong, J. S., \& Overton, T. S. (1977). Estimating nonresponse bias in mail surveys. Journal of Marketing Research, 14, 396-402.

Ary, D., Jacobs, L. C., \& Razavieh, A. (2002). Introduction to research in education. Belmont, CA: Wadsworth.

Bacon, L. D. (1999). Using LISREL and PLS to Measure Customer Satisfaction, Sawtooth Software Conference Proceedings (pp.305-306). La Jolla, California.

Bagozzi, R.P., \& Yi, Y. (1988). On the evaluation of structural equation models. Academy of Marketing Science, 6(1), 74-93.

Bird, R.C. (2005). Employment as a Relational Contract. Journal of Labor and Employment Law, $8,149-166$.

Brewster, C. \& Mayrhofer, W. (2012). Handbook of Research on Comparative Human Resources Management. Edward Elgar Publishing, Northampton, MA.

Carmody, P. (2009). An Asian - driven economic recovery in Africa? The Zambian case. World Development, 37(7), 1197-1207.

Catano, V. W., Wiesner, W. H., Hackett, R. D. \& Methot, L. (2010). Recruitment and selection in Canada ( $4^{\text {th }}$ ed.). Nelson Education, Toronto.

Central Statistical Office. (2013). Zambia Labour Force Survey 2012, Ministry of Labour and Social Security.

Central Statistical Office. (2016). Zambia Labour Force Survey 2014, Ministry of Labour and Social Security.

Chin, W. W. (1998). The partial least squares approach to structural equation modeling. In G. A. Marcoulides (Ed.), Modern methods for business research. (pp.295-336). Mahwah, New Jersey: Lawrence Erlbaum Associates.

Chin, W. W., Marcolin, B. L., \& Newsted, P. R. (1996). A partial least squares latent variable modelling approach for measuring interaction effects: Results from a Monte Carlo simulation study and voice mail emotion/adoption study. Paper presented at the 17th International Conference.

Coyle-Shapiro, J. A. M., \& Conway, N. (2005). Perceived organizational support and employee diligence, commitment, and innovation. Journal of Applied Psychology, 90, 774-781.

Dahie, M. A. (2017). Human Resource Management Practices and Organizational Performance: Case Study from Hormuud Telecom in Mogadishu-Somalia. (pp.78-87). Academic Publishing House, European Researcher Series A.

Derchert-Hampe Consulting [DHC] (n.d) http://www.dechert-hampe.com/index.php/what-wedo/areas-of-focus/39-services/blog-option-content/103-organisation-productivity-model [Accessed 29th October 2018]

Edgar, F., \& Geare, A. (2005). HRM practice and employee attitudes: Different measures different results. Personnel Review, 34(5), 534-549.

Ekwoaba J. O., Ikeije U. U., \& Ufoma N. (2015). The Impact of Recruitment and Selecation Criteria on Organizational Performance. Global Journal of Human Resource Management, $3(2), 22-33$.

Esposito Vinzi, V., Trinchera, L., \& Amato, S. (2010). PLS Path Modeling: From Foundations to Recent Developments and Open Issues for Model Assessment and Improvement. In. V. Esposito Vinzi, W.W. Chin, J. Henseler \& H. Wang (Eds) Handbook of Partial Least Squares: Concepts, Methods and Applications. (pp.47-82). Berlin, Germany: Springer Berlin Heidelberg.

Frank, B. \& Hennig-Thurau, T. (2008). Identifying hidden structures in marketing's structural models through Universal Structure Modeling: An explorative Bayesian Neural Network complement to LISREL and PLS', Marketing. Journal of Research and Management, 4(2), 47-66.

Fornell, C., \& Larcker, D.F. (1981). Evaluating structural equation models with unobservable variables and measurement error. Journal of Marketing Research, 18(1), 39-50.

Haenlein, M. \& Kaplan, A. M. (2004). A beginner's guide to partial least squares analysis. Understanding Statistics, 3(4), 283-297. 
Hafiz, A. Z. (2017). Relationship between organizational commitment and employees' performance evidence from banking sector of lahore. Arabian Journal of Business and Management Review, 7(2), 1-7.

Hair, J. F., Black, W. C., Babin, B. J., \& Anderson, R. E. (2010). Multivariate data analysis (7th ed.). Englewood Cliffs: Prentice Hall.

Hair, J. F., Hult, G. T. M., Ringle, C. M., \& Sarstedt, M. (2013). A Primer on Partial Least Squares Structural Equation Modeling (PLS-SEM). Thousand Oaks: Sage.

Hair, J. F., Ringle, C. M., \& Sarstedt, M. (2011). PLS-SEM: Indeed a silver bullet. Journal of Marketing Theory and Practice, 19(2),139-151.

Hair, J.F., Sarstedt, M., Ringle, C.M. \& Mena, J.A., (2012). An assessment of the use of partial least squares structural equation modeling in marketing research. Journal of the Academy of Marketing Science, 40(3), 414-433.

Henseler, J. (2010). On the convergence of the partial least squares path modeling algorithm. Computational Statistics, 25(1), 107-120.

Henseler. J., \& Sarstedt, M. (2013). Goodness-of-fit indices for partial least squares path modeling. Computational Statistics, 28(2), 565-580.

Henseler, J., Ringle, C., \& Sinkovics, R. (2009). The use of partial least squares path modeling in international marketing. Advances in International Marketing, 20, 277-320.

Hoyle, R. H. (1995). The structural equation modeling approach: Basic concepts and fundamental issues. In R. H. Hoyle (Ed.), Structural equation modeling: Concepts, issues, and applications (pp. 1-15). Thousand Oaks, CA, US: Sage Publications, Inc.

Hulland, J. (1999). Use of partial least squares (PLS) in strategic management research: a review of four recent studies, Strategic Management Journal, 20(2), 195-204.

Hwang, H., Malhotra, N. K., Kim, Y., Tomiuk, M. A., \& Hong, S. (2010). A comparative study on parameter recovery of three approaches to structural equation modeling. Journal of Marketing Research, 47, 699-712.

Igharia, M. \& Greenhaus, J. H. (1992). Determinants of MIS employees' turnover intentions: A structural equation model. Association for Computing Machinery. Communications of the ACM, 35(2), 34-49.

Jansen, D. (1988). Trade, exchange rate and agricultural pricing policies in Zambia, Washington, D.C. The World Bank.

Kanyemba, M., Iwu, C. G., \& Allen-Ile, C. O. K. (2015). Impact of Recruitment and Selection on Organization Productivity. Evidence from Staff of a University in South Africa. Corporate Ownership of Control, 12(2), 177-185.

Karia, O.A., Omari, S., Mwanaongoro, S., \& Ondieki, A. (2016). Impact of recruitment and selection on performance of the public water utilities in tanzania. African Journal of Education and Human Development, 2(1), 39-45.

Kline, R. B. (2005). Principles and practice of structural equation modeling (2nd ed.). New York, NY: Guilford.

Kothari, C. R. (2004). Research Methodology: Methods and Techniques. India: New.

Lambert, D.M., \& Harrington, T.C. (1990). Measuring nonresponse bias in customer service mail surveys. Journal of Business Logistics, 11(2), 5-25.

Macneil, I. (1978). Contracts: Adjustments of Long Term Economic Relations under Classical, Neoclassical and Relational Contract Law 72, Nw,U.L. Rev, 854, 857.

Mercurio, Z. A. (2015). An integrative literature review. Human Resources Development Review, 14(4), 389-414.

Meyer, J. P., \& Allen, N. J. (1991). A three component conceptualization of organizational commitment. Human Resource Management Review, 1, 61-89.

Mohammed, A., Lina, S., \& Phillip, M., (2017). Herzberg's two-factor theory. Life Science Journal, 14(5), 12-16.

Mowday, R. T., Steers, R. M., \& Porter, L. W. (1979). The measurement of organizational commitment. Journal of Vocational Behavior, 14, 224-247. 
Muslim, A., \&. Wan K. W. (2014). The Impact of Human Resource Management Practices on Organizational Performance Evidence from a Public University. TQM Journal, 26(2), 125142.

Musonda, A. (2017). The current labour and employment laws in Zambia. Zambia Educational Publishing House: Lusaka, Zambia.

Niles, N. J. (2013). Basic concepts of health care: Human resources management. Jones \& Bartlett Learning, Burlington, M.A.

Oaya, Z. C.T.O., Ogbu, J. O. \& Remilekun, O. G. (2017). Impact of recruitment and selection strategy on employees' performance: A study of three selected manufacturing companies in Nigeria. International Journal of Innovation and Economic Development, 3(3), 32-43.

Obeidat B. Y., Masa'deh R., \& Abdallah A. B. (2014). The relationship among human resource management practices, organizational commitment and knowledge management processes: A structural equation modeling approach, International Journal of Business and Management. 9(3), 9-26.

Ofobruku S. A., \& Iheabunike O. B., (2013). Assessment of recruitment practice on organization performance: Empirical study of hospitality business in Abuja. European Scientific Journal, 29(9), 294-305.

Ofori, D. \& Aryeetey, M. (2011). Recruitment and selection practices in small and medium enterprises in Ghana. International Journal of Business Administration, 2(3), 45-60.

Opatha, H. H. D. N. P. (2010). Human Resources Management. Colombo.

Petter, S., Straub, D., \& Rai, A. (2007). Specifying formative constructs in information systems research. MIS Quarterly, 31(4), 623-656.

Pushpendra S., Garima M., Monika J., \& Albert S., (2017). Recruitment \& selection and its 1mpact on organizational productivity. International Journal of Core Engineering \& Management. 4, 26-35.

Reinartz, W. J., Haenlein, M. \& Henseler, J. (2009). An empirical comparison of the efficacy of covariance-based and variance-based SEM. International Journal of Market Research, 26(4), 332-344.

Remenyi, D., Williams, B., Money, A. \& Swartz, E. (1998). Doing research in business and management. London: Sage Publications.

Ringle, C., Wende, S., \& Will, A. (2005). SmartPLS 2.0 (Beta). Hamburg.

Sangeetha, K. (2010). Effective recruitment: A framework. IUP Journal of Business Strategy. 7(1/2), 93-107.

Seeck, H. \& Parzefall, M. (2010). From hrm to psychological contracting - the case of Finnish mobile content producing companies. The International Journal of Human Resource Management, 21(15), 2677-2693.

Sosik, J., Kahai, S, \& Piovoso, M. J. (2009). Silver bullet or voodoo statistics? A primer for using the partial least squares data analytic technique in group and organization research. Emerald Management Reviews: Group \& Organization Management, 34(1), 5-36.

Speidel, R., E. (2000). The characteristics and challenges of relational contract. Nw. UL Rev, 94, 823-828.

Statsoft, (2013). Structural equation modeling: Statsoft electronic statistics textbook. Tulsa, OK: StatSoft.

Stefania, D. S. (2015). Expectancy value theory: Motivating healthcare workers. American International Journal of Contemporary Research, 5(2), 19-23.

Syverson, C. (2010). What determines Productivity? (No.W15712) National Bureau of Economic Research.

Wold, H. (1973). Nonlinear Iterative Partial Least Squares (NIPALS) Modeling: Some Current Developments, in Paruchuri R. Krishnaiah (Ed.), Multivariate Analysis. Vol. 3, New York: Academic Press. 3, 383-407.

Wold, H. (1985). Partial Least Squares. In S. Kotz\& N. L. Johnson (Eds.), Encyclopedia of Statistical Sciences, New York: John Wiley \& Sons. 6, 581-591. 
Wong, C., Hui, C., \& Law, K. S. (1995). Causal relationship between attitudinal antecedents to turnover. Academy of Management Journal, 4, 342-346.

Wong, K. K. (2010). Handling small survey sample size and skewed dataset with partial least square path modeling. Vue: The Magazine of the Marketing Research and Intelligence Association, 20-23.

Wong, K. K. (2011). Review of the Handbook of Partial Least Squares: Concepts, Methods and Applications, by V. Esposito Vinzi, W.W. Chin, J. Henseler \& H. Wang.

Yesufu, L. (2016). The Effect of Human Resource Practices on the Psychological Contract of Academics. Doctor of Business Administration (DBA). 